\title{
LABORATORY DEVELOPMENT OF FINANCIAL MANAGEMENT BASED ON DATA CENTER IN ECONOMIC FACULTY AND BUSINESS IBI DARMAJAYA
}

\author{
Susansti ${ }^{1}$, Herlina ${ }^{2}$, Emanuel Kristijadi ${ }^{3}$, Nanang Shonhadji ${ }^{4}$ \\ ${ }^{1.2}$ Faculty of Economics and Business Institute of Informatics and Business Darmajaya \\ ${ }^{3.4}$ High School of Economics of Perbanas \\ Email: ${ }^{1}$ susanti@darmajaya.ac.id; ${ }^{2}$ herlina@darmajaya.ac.id
}

\begin{abstract}
The purpose of the laboratory development is carried out by cooperating with the Partner Research Team (TPM) derived from STIE Perbanas Surabaya. The stages of the research are done that there are 2 stages. The first stage is the layout of the laboratory, cooperation with agencies, data collection, development concepts, and Design Lab.Manajemen Finance, Marketing, and HR. The second stage is already available laboratory-based data center and performs competency test students concentration of financial management, marketing, and human resources. At this stage issued a Certificate of Competency Test as a certificate of companion diploma for students who pass the competency test. In the first year, it is done at partner universities and partner colleges. In the year 1, has been designed layout laboratory, has been established cooperation with the agency Capital Market Information Center and Securities Company, data collection, development concepts, and Design Lab.Manajemen Management, Marketing, and HR.
\end{abstract}

\section{Keywords: Laboratory, Financial Management}

\section{INTRODUCTION}

According to the Regulation of the State Minister of Administrative Reform and Bureaucratic Reform No.03 / January / 2010 and Joint Regulation of the Minister of National Education and Head of State Employment Agency No.02 and No.13 / May / 2010, the educational laboratory is the academic support unit of the institution education, in the form of closed or open space, permanent or mobile, systematically managed for limited testing, calibration and production activities, using equipment and materials based on certain scientific methods, in the context of educational, research and community service implementation; personnel who have the scope of duties, responsibilities, and authority to manage the Education Laboratory Department of Management Faculty of Economics and Business Institute of Informatics and Business Darmajaya has several courses taught in the Department of Management requires a laboratory as a media application of theories being taught. Where currently the concentrations in 
the Management Department have not offered Laboratory courses in accordance with their respective courses while the Management Laboratory has an important role in scientific development efforts in the Department of Management Institute of Informatics and Business Darmajaya.

The existence of accredited and accredited college laboratories by implementing an international laboratory quality management system with APLAC is the collaboration of accreditation bodies in the Asia Pacific region that accredit laboratories, inspection bodies, and reference material manufacturers. It is recognized by the Asia Pacific Economic Cooperation (APEC) as one of the five Regional Specialist Bodies (BPRS), ILAC is an international organization for accreditation bodies operating in accordance with ISO / IEC 17011 and is involved in accreditation of conformity assessment bodies including calibration laboratories (using ISO / IEC 17025), testing laboratories (using ISO / IEC 17025), laboratory medical testing (using ISO 15189) and inspection bodies (using ISO / IEC 17020). The IAF is a worldwide association of the Accreditation Conformity Assessment Board and other bodies interested in conformity assessment in the areas of management systems, products, services, personnel and other similar programs of conformity assessment. Accredited laboratories will ensure the activities of students and educators, coupled with roleplay learning methods for students as a foundation for exploring relationships by demonstrating and discussing them together so learners can explore feelings, attitudes, values, and various problemsolving strategies. As a learning model, roleplay is rooted in the personal and social dimension that students will become familiar with with the practice of true laboratories. This insight will be useful later when they work in industries or companies that generally implement quality management system standards. The availability of professionally accredited laboratories will demonstrate the spirit of Excellent Service and have a positive impact on the improvement of academic quality, which is highly relevant to the Directorate General of Higher Education's strategic plan which mandates the improvement of education quality to strengthen the nation's competitiveness and the Ministry of National Education's strategic plan for improving the quality and relevance of education. Therefore, the laboratory is the spearhead for students and lecturers in conducting research to produce quality findings and potentially commercial/patent in order to support the achievement of the ideals of world-class university.

\section{LITERATURE REVIEW}




\section{Laboratory}

The laboratory is the venue for practicum activities. As one of the supporting facilities for learning activities, the presence of laboratories in universities is very important because in it there are laboratory equipment and other supporting infrastructure. Ketut in Salam (2010) states that: A laboratory is a place for learners to experiment with the theories that have been given in the classroom. The function of the experiment itself as a supporter of learning to improve students' understanding of a material that has been studied. The function of the laboratory as a place of practical learning activities that require special equipment that is not easily presented in the classroom. Depdiknas (2002) suggests that: The laboratory is a place to apply scientific theories, theoretical testing, proof of trials, research and so forth by using tools that become the completeness of facilities with adequate quantity and quality. Novianti (2011: 3) argues that the laboratory and the type of equipment is an important means and infrastructure to support the learning process in schools. Meanwhile, according to Koesmadji in Afwah (2012:7) states that the laboratory is defined as a place that can take the form of open space, enclosed space, school gardens, greenhouses or another environment to conduct experiments or research. ISO / IEC 17025, Laboratory Competency Standards ISO / IEC 17025 is a standard of competence requirements for laboratories. Required requirements are common to the various types and sizes of organizations conducting tests and/or calibrations. The scope of this standard includes testing and calibration with standard methods, standard methods, and methods developed by the laboratory itself. The full title of this standard is ISO / IEC 17025 General requirements for the competence of testing and calibration laboratories. National Accreditation Committee translates under ISO / IEC 17025 General Requirements of Competence of Testing Laboratory and Calibration Laboratory. Developing Laboratory Quality The first edition of this standard was published in 1999, to be subsequently revised with the second edition of 2005 that aligns to ISO 9001: 2000. These standards are designed to conform to ISO 9001 principles. Some of the requirements of ISO 9001 can also be found in this international standard. However, the ISO / IEC 17025 conformity applied by the laboratory does not automatically satisfy all ISO 9001 requirements. The implementation of this international standard management system also does not guarantee by itself the technical validity of any data and reports produced.

\section{ILAC, IAF, APLAC}


ILAC is an international organization for accreditation bodies operating in accordance with ISO / IEC 17011 and is involved in accreditation of conformity assessment bodies including calibration laboratories (using ISO / IEC 17025), laboratory testing (using ISO / IEC 17025), laboratory medical testing (using ISO 15189 ) and inspection bodies (using ISO / IEC 17020). Accreditation bodies established in many countries with the primary objective of ensuring that conformity assessment bodies are subject to supervision by authoritative bodies. Accreditation bodies, which have been peers evaluated as competent, significant regional and international agreements to demonstrate their competence. The accreditation body then assesses and accredits the conformity assessment bodies to the relevant standards.

\section{Certification}

The definition of certification under the International Institute for Environment Development (IIED) is a procedure by which a third party provides a written warranty that a product, service process has met certain standards, based on audits carried out by agreed procedures. Certification deals with product labeling for the market communication process. (http://www.iied.org/). Certification, in this case, will be given to laboratories, layouts, and students who have passed the competency test that has been held. So in this case certification can be defined as the process of granting certificates for laboratories, layouts, and students. Laboratory certification, layout, and students are formal proofs as recognition given to the laboratory, layout, as a means of education and students as students.

\section{Competence}

Determination of the meaning of Competence in Decree of the Minister of National Education no. 232 / U / 2002 is a set of intelligent, responsible actions, which a person possesses as a condition of ability to perform tasks in a particular field of work. In the Decree of the Minister of National Education no. 045 / U / 2002, A competent person must be able to fulfill the requirements: 1) The foundation of personality development ability, (ii) knowledge and knowhow skills, 2) Know-how, 3) Ability to behave and behave in the work so as to be independent, judge and take decisions responsibly (to be), and 4) Can live in society by cooperating, mutual respect and appreciate the values of pluralism, and peace (to live together). Someone will be said to be competent in a field if it has fulfilled 3 domain of competence in that field, that is Skill 
domain (Skill / Psychomotor), Knowledge (Knowledge / Cognitive) domain and Attitude domain (Attitude / Affective).

\section{Data center}

The data center is a facility used for placement of several servers and components terakaitnya, such as telecommunications systems and data storage. These facilities typically include redundant or backup power chess, redundant data communications connections, environmental controllers, fire prevention, and physical security devices. The data center is managed by an administrator. The data center in science management is the provision of human resource management data, marketing of the built ukm data, and financial data.

\section{RESEARCH METHODST}

types of research method used is a qualitative method. According to McMillan \& Scumacher (2003), qualitative research is an approach also called investigative approach because usually researchers collect data by face to face face-to-face and interact with people in place of research. Meanwhile, according to Strauss \& Corbin (2003), qualitative research can also be intended as a type of research whose findings are not obtained through statistical procedures or other forms of calculation.Role Playing Learning MethodActions done in the learning process is by using a role-playing approach. 

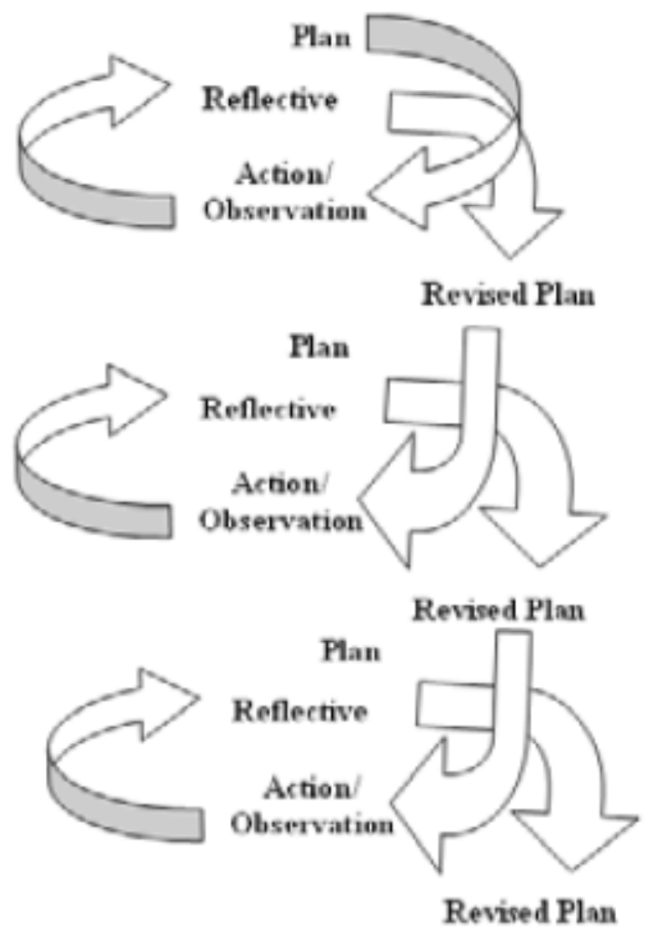

\section{RESULTS AND DISCUSSION}

Financial Management LaboratoryThe simulation application of stock trading and log in first.

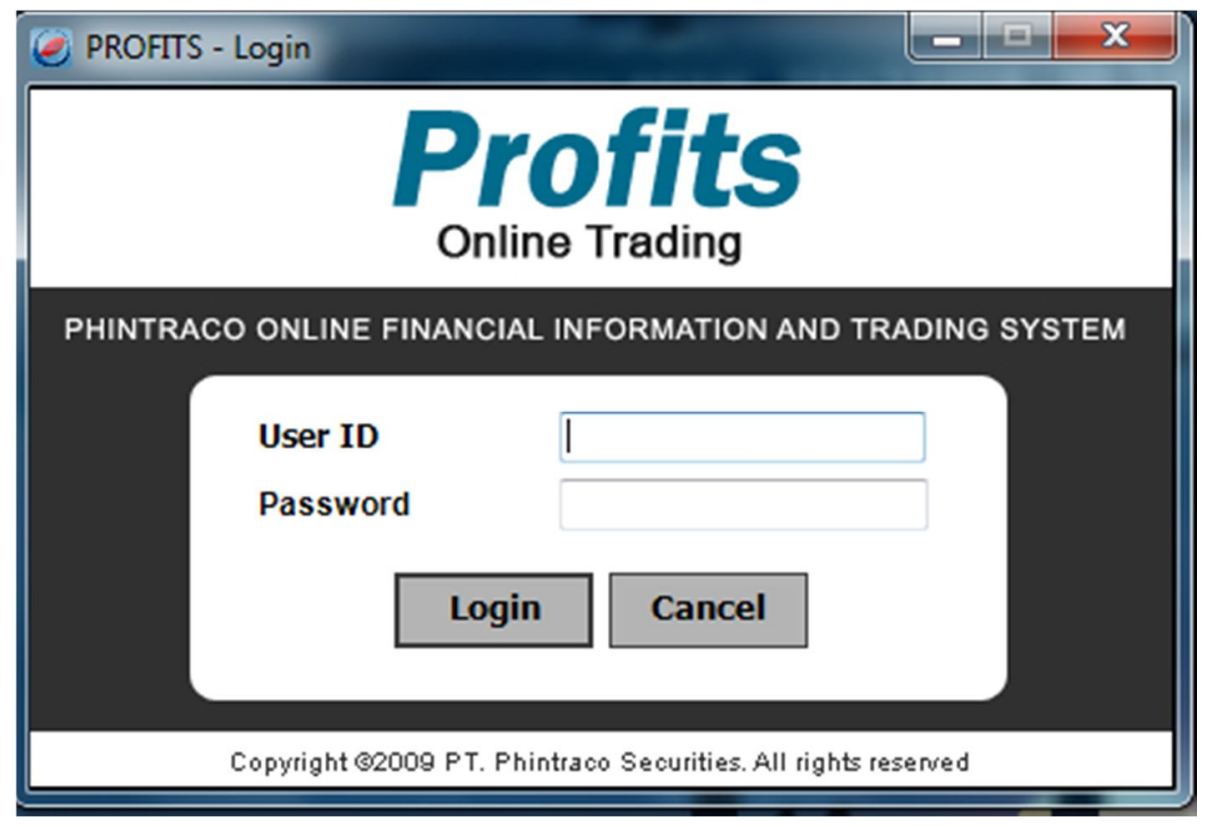

Figure 4.1 Login

Student must enter user id and password that have been made of lecture oleh dosen. 


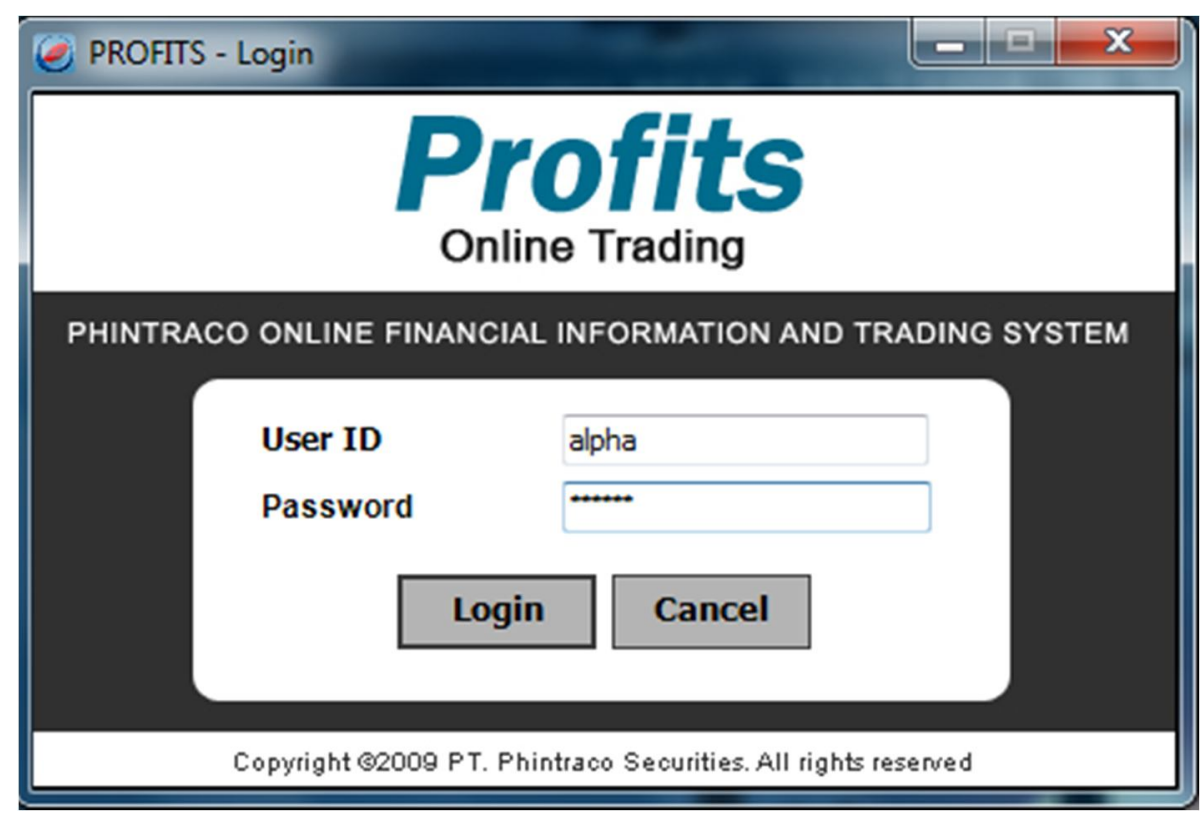

\section{Gambar 4.2 Login Info}

After the student login, the system will display the main screen of a stock trading simulation program. Here's how it looks.

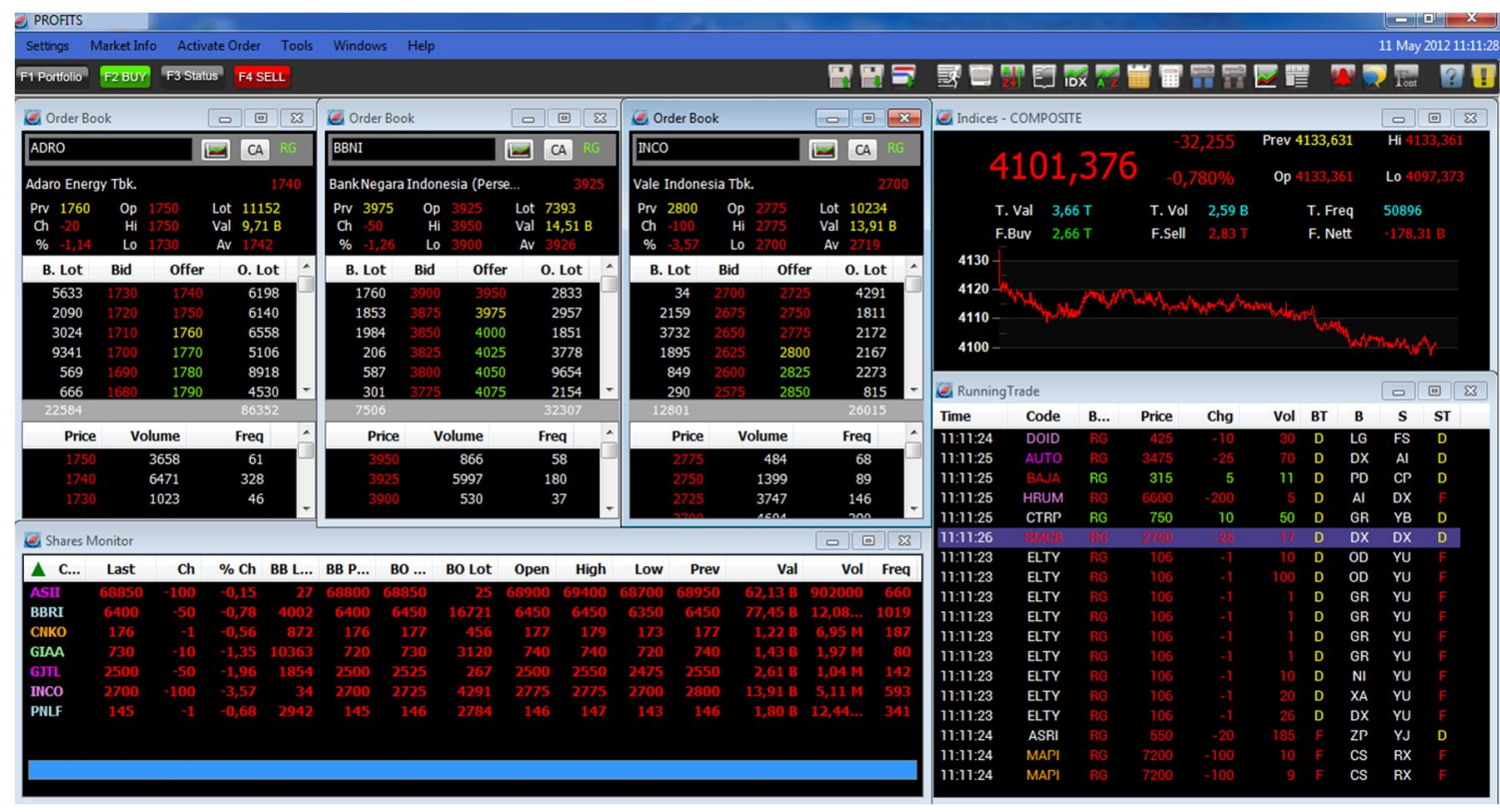

\section{CONCLUSION}

\section{Gambar 4.3 Main Screen}

1. Development of Financial Management Laboratory has been successfully developed and has been built simulation application of stock trading so that students can practice the 
knowledge gained and can follow the competency test from the Indonesia Stock Exchange. While the other two concentrations of human resource management and marketing management for the laboratory are ready, but for application, cooperation and certification are being designed.

2. Stock trading simulation application has been successfully built.

3. Training on the development of Laboratory of Financial Management, Human Resource Management, and Marketing Management has been successfully implemented.

\section{SUGGESTION}

1. To find out whether the stock trading simulation application can run well and can improve the competence of students in financial management concentration, it is advisable to do a trial either in software, hardware, and the competence of lecturers and students.

2. Lecturers who will teach concentration courses especially in this laboratory should have certification in their respective fields - each.

\section{BIBLIOGRAPHY}

Abul, Salam, 2010. Environmental and Health Impact of Solid Waste Disposal at Mangwaneni Dumpsite in Manzini: Swaziland, Journal of Sustainable Development in Africa Volume 12, No.7

Blessing. 2012. Management of Biology Laboratory SMA Negeri 1 Demak And SMA 3 Demak In Supporting Implementation of Biology Learning. Essay. Semarang: IAIN Walisongo. Dewi Susilowati. 2012. Efforts to Improve the Ability of Critical Thinking Through Cooperative Script Learning Methods In Class IPS Subjects VII A SMP N 4 Kalasan. http://eprints.uny.ac.id/8556/.

Dawn, Arnie. (2006). The role of teacher certification in improving teacher professionalism. Bandung: Disdik West Java.

Hudha, A, M. 2011. Analysis of Management of Biological Practicum in the Biology Laboratory University of Muhammadiyah Malang. Essay. Malang: UMM. Jalal, Fasli et al. (2007). Guidelines for the determination of participants and the implementation of certification of teachers in the office. Jakarta: National Education Department Directorate of Education in 2007.

McMillan, James H., \& Sally Schumacher. 2006. Research in Education. New Jersey: Pearson Mulyasa. 2007. Competency Standards and Teacher Certification. Bandung: Teens Rosdakarya.

Novianti, N. R. 2011. The contribution of Laboratory Management and Student Motivation to 
the Effectiveness of the Process of Traveling. Journal of Natural Science Special Edition No. 1 thing: 159. ISSN 1412-565X.

Sanaky, Hujair. 2004. Learning Media. Yogyakarta. Safiria Insania Press Sugiyono., 2010. Administration Research Method. Bandung. Alfabeta Publisher. Suranta, Eddy, and Pratana Puspita Merdistusi. 2004. Income Smoothing, Tobin's Q, Agency Problems and Corporate Performance. National Symposium on Accounting VII. Bali, 2 - 3 December.

Strauss, Anselm \& Juliet Corbin, 2003. Fundamentals of Qualitative Research. Yogyakarta. Student Library.

Document

Decree of the Minister of National Education no. 232 / U / 2002

Decree of the Minister of National Education no. 045 / U / 2002

Regulation of the State Minister for Administrative Reform and Bureaucratic Reform No.03 / January / 2010 and Joint Regulation of the Minister of National Education and Head of State Employment Agency No.02 dan No.13 / Mei / 2010

Law No. 14 of 2005 in MoNE, 2004

http://www.iied.org/ 